\title{
PEMANFAATAN MEDIA PEMBELAJARAN BERBASIS WEBSITE PADA PROSES PEMBELAJARAN PRODUKTIF DI SMK
}

\author{
Syaiful Rahman ${ }^{1}$, Wahid Munawar ${ }^{2}$, Ega T. Berman ${ }^{3}$ \\ Departemen Pendidikan Teknik Mesin, FPTK UPI \\ Jl. Dr. Setiabudi No. 207 Bandung 40154 \\ syaiful_netralis@yahoo.co.id
}

\begin{abstract}
ABSTRAK
Penelitian ini bertujuan untuk mengetahui pengaruh pemanfaatan media pembelajaran berbasis website terhadap hasil belajar kognitif siswa pada mata pelajaran Kelistrikan Sistem Refrigerasi. Metode penelitian yang digunakan adalah kuasi eksperimen dengan desain one group pretest-posttest. Pengumpulan data dilakukan menggunakan angket pemanfaatan media pembelajaran berbasis website dan tes objektif untuk hasil belajar kognitif. Hasil penelitian menunjukkan bahwa terdapat pengaruh yang sedang pemanfaatan media pembelajaran berbasis website terhadap hasil belajar kognitif siswa. Pemanfaatan media pembelajaran berbasis website dapat diimplementasikan dalam proses pembelajaran produktif.
\end{abstract}

Kata kunci: media pembelajaran, hasil belajar, pembelajaran produktif

\section{PENDAHULUAN}

Kemampuan menggunakan Teknologi Informasi dan Komunikasi (TIK) kini merupakan hal pokok yang harus dimiliki oleh setiap pendidik, tenaga kependidikan dan peserta didik. Pemerintah mensyaratkan kemampuan menggunakan TIK bagi siswa SMK/MAK melalui lampiran Permendiknas nomor 23 tahun 2006 tentang Standar Kompetensi Lulusan (SKL). Salah satu Standar Kompetensi Kelompok Mata Pelajaran (SK-KMP) IPTEK yang harus dikuasai oleh siswa SMK/MAK berdasarkan Lampiran Permendiknas Nomor 23 Tahun 2006 adalah berkomunikasi dan berinteraksi secara efektif dan santun melalui berbagai cara termasuk pemanfaatan teknologi informasi.

Saat ini cukup banyak siswa yang lebih tertarik mencari informasi dari internet dibandingkan media lainnya. Begitu pun informasi yang berkaitan dengan materi pembelajaran. Ketersediaan media pembelajaran yang terbatas di sekolah menjadikan siswa lebih tertarik memanfaatkan internet sebagai sumber belajar.

\footnotetext{
${ }^{1}$ Mahasiswa Departemen Pendidikan Teknik Mesin FPTK UPI

${ }^{2}$ Dosen Departemen Pendidikan Teknik Mesin FPTK UPI

${ }^{3}$ Dosen Departemen Pendidikan Teknik Mesin FPTK UPI
} 
Guru sebagai fasilitator pembelajaran harus mampu menyediakan fasilitas dan media yang memudahkan siswa dalam belajar. Guru SMK sebagai tenaga pendidik pun harus mampu menggunakan dan mengembangkan TIK secara profesional yang diimplementasikan dalam pembelajaran. Melalui implementasi TIK khususnya media internet dan website maka proses pembelajaran diharapkan lebih berpusat kepada siswa (student centered) sehingga hasil belajar akan meningkat.

Tujuan penelitian ini untuk mengetahui pengaruh dan kontribusi pemanfaatan media pembelajaran berbasis website terhadap hasil belajar kognitif siswa pada mata pelajaran Kelistrikan Sistem Refrigerasi. Bagi Kepala Sekolah dan Ketua Kompetensi Keahlian, hasil penelitian dapat dijadikan masukan untuk memfasilitasi guru dan siswa SMK dalam pemanfaatan TIK terutama internet dan website. Bagi guru, website dapat dijadikan media pembelajaran alternatif untuk meningkatkan hasil belajar siswa dan kemampuan TIK. Pemanfaatan website diharapkan dapat membiasakan siswa untuk aktif dalam belajar sehingga pembelajaran lebih bersifat student centered. Hasil penelitian dapat meningkatkan minat siswa untuk memanfaatkan website sebagai sumber belajar.

Media pembelajaran adalah media yang dirancang secara khusus untuk merangsang pikiran, perasaan, perhatian, dan kemauan peserta didik sehingga terjadinya proses pembelajaran. Media pembelajaran memuat informasi yang dapat berupa pengetahuan maupun menjadi sarana bagi siswa untuk melakukan aktivitas belajar (membaca, mengamati, mencoba, mengerjakan soal, menjawab pertanyaan, dan lain-lain). Media pembelajaran bukan sekedar benda fisik, namun segala sesuatu yang sudah berisi materi pembelajaran, sehingga memungkinkan seseorang memanfaatkannya untuk belajar guna memperoleh pengetahuan, keterampilan, atau perubahan sikap (Sahid, 2010).

Pemanfaatan media adalah penggunaan secara sistematis dari sumber belajar. Fungsi pemanfaatan sangat penting karena membicarakan kaitan antara peserta didik dengan bahan belajar atau sistem pembelajaran (Warsita, 2008:37). Beberapa pola pemanfaatan media pembelajaran (Furqan, 2012), yaitu:

1. Pemanfaatan media dalam situasi kelas atau di dalam kelas, yaitu media pembelajaran dimanfaatkan untuk menunjang tercapainya tujuan tertentu dan pemanfaatannya dipadukan dengan proses belajar mengajar dalam situasi kelas.

2. Pemanfaatan media di luar situasi kelas atau di luar kelas, meliputi: 
a. Pemanfaatan secara bebas yaitu media yang digunakan tidak diharuskan kepada pemakai tertentu dan tidak ada kontrol dan pengawasan dari pembuat atau pengelola media, serta pemakai tidak dikelola dengan prosedur dan pola tertentu.

b. Pemanfaatan secara terkontrol yaitu media itu digunakan dalam serangkaian kegiatan yang diatur secara sistematik untuk mencapai tujuan pembelajaran yang telah ditentukan untuk dipakai oleh sasaran pemakai (populasi target) tertentu dengan mengikuti pola dan prosedur pembelajaran tertentu hingga mereka dapat mencapai tujuan pembelajaran tersebut.

c. Pemanfaatan media secara perorangan, kelompok atau masal.

World Wide Web (www) disebut juga web, site, website atau situs adalah aplikasi dan layanan internet yang mencakup sumber daya multimedia (Rusman et al., 2012). Web secara fisik adalah kumpulan komputer pribadi, web browser, koneksi ke ISP, komputer server, router, dan switch yang digunakan untuk mengalirkan informasi dan menjadi wahana pertama berbagai pihak terkait (Oetomo et. al., 2007). Jenis-jenis website yang dimanfaatkan oleh siswa pada penelitian ini dibatasi pada search engine, blog, web portal dan web perusahaan yang bersifat dinamis maupun statis. Pemanfaatan jaringan internet sebagai sumber dan sarana pembelajaran dapat diimplemetasikan, sebagai berikut:

1. Browsing atau surfing merupakan istilah umum yang digunakan bila hendak menjelajahi dunia maya atau web.

2. Resourcing adalah menjadikan internet sebagai sumber pengajaran. Peranan internet sebagai gudangnya informasi dimanfaatkan untuk mendapatkan informasi dan data yang berkaitan dengan materi pengajaran yang disampaikan. Informasi yang berkaitan dengan alamat situs yang akan dikunjungi sebagai sumber materi ajar telah diketahui terlebih dahulu melalui informasi yang diberikan pada buku pegangan pengajaran maupun dari informasi lainnya.

3. Searching merupakan proses pencarian sumber pembelajaran guna melengkapi materi yang akan disampaikan kepada peserta didik.

4. Consultingandcommunicating(konsultasi dan komunikasi melalui e-mail dan mailing list). 
Pencarian informasi yang diinginkan di media internet menjadi lebih mudah dengan menggunakan search engine. Search engine menampung database situs-situs dari seluruh dunia yang jumlahnya milyaran halaman web. Cukup dengan memasukkan kata kuncinya, maka proses pencarian akan dilakukan dan search engine akan menampilkan beberapa link situs yang disertai dengan keterangan singkat (Adri, 2007).

Secara umum website dibagi menjadi beberapa jenis. Penjelasan jenis-jenis website yang dimanfaatkan pada penelitian ini yaitu:

1. Web search engine adalah web yang memiliki kemampuan untuk melakukan pencarian dokumen berdasarkan kata kunci tertentu. Contoh: Google dan Alltheweb.

2. Web portal adalah web yang berisi kumpulan link, search engine, dan informasi. Contoh: Yahoo dan AOL.

3. Web perusahaan adalah web yang mendeskripsikan suatu perusahaan, layanan, fasilitas, dan segala sesuatu tentang perusahaan. Contoh: Andi Publisher dan Indosat.

4. Weblog atau sering disingkat blog ialah situs internet yang memungkinkan pemiliknya dapat menuliskan apa pun yang menjadi opini atau pandangan pengguna terhadap sesuatu serta catatan harian atau diari. Pengguna internet yang membuat atau memiliki blog disebut blogger.

Proses belajar pada diri siswa merupakan sesuatu yang unik, terjadi melalui usahausaha terencana yang menghasilkan perubahan tingkah laku. Hasil belajar dapat berupa perubahan dalam kemampuan kognitif, afektif dan psikomotorik. Hasil belajar merupakan perubahan tingkah laku akibat belajar. Hasil belajar merupakan pencapaian tujuan pendidikan pada siswa yang mengikuti proses belajar mengajar (Purwanto, 2011).

\section{METODE PENELITIAN}

Penelitian ini menggunakan metode kuasi eksperimen. Desain penelitian yang digunakan adalah one group pretest-posttest design. Kelompok eksperimen diberi pre test hasil belajar untuk mengetahui kemampuan kognitif awal para siswa pada mata pelajaran Kelistrikan Sistem Refrigerasi. Peneliti kemudian membuka website yang berisi materi pembelajaran. Siswa diminta membuka website yang sama kemudian membaca materi pembelajaran. Peneliti melakukan tanya jawab dengan siswa mengenai materi pembelajaran. Selanjutnya peneliti mendemonstrasikan pencarian materi pembelajaran 
(searching) dan cara mengunduhnya (download) dari halaman website menggunakan search engine. Siswa mengikuti tahapan yang dilakukan peneliti. Peneliti mengawasi siswa supaya mereka hanya memanfaatkan website untuk kegiatan belajar.

Treatment (perlakuan) berlangsung di kelas selama 4,5 jam (dua pertemuan). Setelah selesai pertemuan pertama, peneliti menugaskan siswa secara individu untuk mencari materi pembelajaran di luar jam belajar sebagai bentuk pengayaan. Tugas tersebut dikumpulkan pada pertemuan kedua. Perlakuan yang diberikan pada pertemuan kedua pun sama dengan pertemuan pertama. Pemanfaatan website dilakukan secara perorangan dan juga kelompok. Setelah dilakukan perlakuan, seluruh siswa diberi post test hasil belajar. Skor post test hasil belajar dibandingkan dengan skor pre test, sehingga dapat diketahui pengaruh treatment yang diberikan kepada siswa.

\section{HASIL PENELITIAN}

Berdasarkan perhitungan skor, diketahui bahwa 87,5\% siswa memperoleh skor pemanfaatan media pembelajaran berbasis website lebih dari rata-rata teoritis, tidak satu pun siswa memperoleh skor pre test hasil belajar lebih dari rata-rata teoritis dan $78,1 \%$ siswa memperoleh skor post test hasil belajar lebih dari rata-rata teoritis. Peningkatan ratarata skor hasil belajar dari 6,59 menjadi 12,44. Hanya satu orang siswa yang tidak mengalami peningkatan skor. Berdasarkan hasil uji normalitas, diketahui bahwa data angket pemanfaatan media pembelajaran berbasis website, pre test dan post test hasil belajar terdistribusi normal.

Hasil perhitungan diperoleh persamaan regresi $\hat{Y}=27,52+0,45 X$. Hal ini berarti untuk setiap penambahan skor variabel X sebesar satu point, maka terjadi penambahan skor variabel $Y_{1}$ sebesar 0,45 . Pemanfaatan media pembelajaran berbasis website berpengaruh sedang terhadap hasil belajar siswa. Berdasarkan hasil perhitungan koefisien determinasi, diperoleh temuan bahwa pemanfaatan media pembelajaran berbasis website memiliki kontribusi sebesar 20,22\% terhadap hasil belajar kognitif siswa pada mata pelajaran Kelistrikan Sistem Refrigerasi.

Hasil pengujian hipotesis, diperoleh $t_{\text {hitung }}>t_{\text {Tabel }}(11,66>1,67)$ pada $\alpha=0,05$; maka $\mathrm{H}_{0}$ ditolak. Hal ini berarti terdapat pengaruh yang positif pemanfaatan media pembelajaran 
berbasis website terhadap hasil belajar kognitif siswa pada mata pelajaran Kelistrikan Sistem Refrigerasi.

\section{PEMBAHASAN}

Keragaman aplikasi website yang dimanfaatkan oleh siswa cukup tinggi. Sekitar setengah dari jumlah siswa pernah mencari informasi dari website yang berisi materi pembelajaran, biasa melakukan posting pada halaman website dan menuliskan komentar (comment) terhadap informasi di halaman website. Selain interpretasi tersebut, masih terdapat jawaban (respon) negatif yang cukup besar dari siswa. Sebagian besar siswa tidak biasa mencari gambar komponen kelistrikan pada halaman website. Beberapa orang siswa pun menjawab ragu-ragu pada setiap butir angket sehingga tidak diketahui secara pasti kegiatan pemanfaatan website yang mereka lakukan.

Frekuensi penggunaan website oleh siswa pun cukup tinggi. Hal ini terlihat dari jawaban siswa terhadap butir angket. Setiap kali mencari materi pembelajaran dari website secara mandiri, hampir setengah dari jumlah siswa memerlukan waktu rata-rata satu jam sampai dua jam dengan frekuensi satu sampai tiga kali per minggu. Setiap mencari materi pembelajaran dari website secara berkelompok, hampir setengah dari jumlah siswa memerlukan waktu 31 sampai 45 menit, dan hampir setengah lainnya memerlukan waktu lebih dari 45 menit. Hampir setengah dari mereka mengakses website satu sampai tiga kali per bulan untuk mencari materi pembelajaran secara berkelompok.

Peran peneliti dalam pembelajaran adalah mengontrol kegiatan pemanfaatan website yang dilakukan para siswa. Para siswa yang kesulitan dalam mengakses website dan memahami materi pembelajaran, diberi penjelasan lebih lanjut oleh peneliti. Setelah memperoleh penjelasan, sebagian besar siswa pun dapat melakukan searching (menggunakan search engine), browsing dan resourcing (menjadikan website sebagai sumber belajar). Namun demikian, siswa masih harus dilatih untuk menggunakan kata kunci secara spesifik dalam proses pencarian (searching), penggunaan perintah restore pada menu history, dan pemanfaatan link media gambar.

Kata kunci yang dapat digunakan secara spesifik meliputi pencarian acak, pencarian berdasarkan kategori dan pencarian khusus (pencarian dalam link, pencarian dalam URL 
dan lain sebagainya). Kata kunci spesifik yang digunakan dalam proses searching akan mempermudah siswa untuk memperoleh materi pembelajaran dari website.

Selanjutnya siswa pun harus dibiasakan untuk memilih materi pembelajaran yang relevan dengan materi pembelajaran yang disampaikan oleh guru di kelas. Penerapan metode diskusi antar siswa maupun antara siswa dan guru di kelas dapat dijadikan kegiatan transfer informasi dari website kepada peserta diskusi. Ilmu pengetahuan yang berkembang pesat dapat ditransfer dengan lebih mudah melalui pemanfaatan website dalam pembelajaran.

Jenis-jenis media dan informasi yang terdapat pada halaman website dipublikasikan dalam bahasa asing maupun bahasa Indonesia. Penggunaan bahasa asing pada website tersebut secara tidak langsung diduga dapat meningkatkan kemampuan berbahasa para siswa. Walaupun tidak meningkatkan kemampuan berbahasa secara aktif, tetapi diduga kosakata bahasa asing para siswa akan meningkat. Para siswa pun akan mampu bertukar informasi, terutama melalui proses posting pada weblog.

Berdasarkan temuan ini, berarti aktivitas dan frekuensi siswa berkategori sedang dalam memanfaatkan website untuk kepentingan pembelajaran. Aktivitas siswa dalam memanfaatkan website juga dapat ditujukan untuk kepentingan lain yang tidak berhubungan dengan pembelajaran, seperti untuk komunikasi melalui web atau mempublikasikan file di halaman web. Aktivitas ini pun dapat menghindarkan para siswa dari gagap teknologi dan membiasakan diri untuk berinteraksi dengan konten atau media berbasis website.

Pemanfaatan website memungkinkan kita untuk mengakses serta memperoleh informasi dari teks, grafik, gambar, foto, animasi, audio dan video. Penelitian ini hanya sebatas memanfaatkan media teks dan Gambar, sehingga masih kurang variatif. Penelitian selanjutnya perlu dilakukan pemanfaatan jenis media lain yang ada di dalam website sehingga diharapkan mampu meningkatkan perhatian dan hasil belajar siswa lebih baik lagi.

Analisis data pre test menunjukkan bahwa para siswa memiliki kemampuan aspek kognitif awal yang rendah. Setelah diberikan perlakuan dengan memanfaatkan media pembelajaran berbasis website, hasil belajar mengalami peningkatan secara signifikan. Meskipun terjadi peningkatan, tetapi sebagian besar siswa memperoleh hasil belajar yang 
rendah (belum mencapai KKM). Pemanfaatan media pembelajaran berbasis website berpengaruh sedang terhadap hasil belajar kognitif. Berdasarkan persamaan regresi, diketahui bahwa pengaruh pemanfaatan media pembelajaran berbasis website terhadap hasil belajar kognitif lebih kecil dibandingkan pengaruh faktor lainnya.

Faktor-faktor yang diduga menjadi penyebab rendahnya hasil belajar siswa yaitu sebagian besar siswa menanyakan materi pembelajaran yang tidak dimengerti secara langsung kepada peneliti, padahal materi tersebut sudah ada di halaman website. Para siswa pun sudah ditugaskan untuk membacanya, tetapi sebagian besar diantara mereka tidak membaca materi pembelajaran tersebut secara keseluruhan. Hal ini mengindikasikan bahwa minat membaca para siswa masih cukup rendah. Sebagian besar siswa tidak biasa mencari dan membuka link media gambar komponen kelistrikan pada halaman website sehingga mereka tidak bisa menjawab soal tes yang berkaitan dengan gambar komponen kelistrikan. Sebagian siswa pun tidak mengerjakan tugas yang telah peneliti berikan.

Sebagian siswa tidak menunjukkan aktivitas yang sesuai dengan harapan peneliti karena mereka kurang aktif dalam pembelajaran. Berdasarkan pengamatan peneliti, siswa tersebut kurang termotivasi untuk belajar meskipun telah diberikan perlakuan dengan media pembelajaran berbasis website. Peneliti pun menduga bahwa diperlukan konten, tampilan dan media interaktif website yang lebih menarik perhatian siswa sehingga dapat menumbuhkan motivasi belajar mereka. Konten, tampilan dan media interaktif tersebut memungkinkan siswa untuk melihat dan mendengar materi pembelajaran, mengerjakan tugas, latihan soal, bahkan ujian dan daftar nilai. Hal yang penting untuk diteliti selanjutnya adalah melibatkan motivasi belajar di samping hasil belajar siswa.

Hasil pada penelitian ini bertolak belakang dengan hasil penelitian bahwa tingkat pemanfaatan e-learning berpengaruh negatif dan tidak signifikan terhadap hasil belajar (Edy, 2010). Hal ini menandakan bahwa perlakuan yang peneliti berikan kepada siswa lebih baik dibandingkan perlakuan pada penelitian tersebut. Perlakuan yang peneliti berikan berpengaruh lebih tinggi terhadap hasil belajar siswa dibandingkan perlakuan pada penelitian tersebut. 


\section{KESIMPULAN}

Kesimpulan penelitian ini yaitu terdapat pengaruh yang sedang dan kontribusi rendah pemanfaatan media pembelajaran berbasis website terhadap hasil belajar kognitif siswa pada mata pelajaran Kelistrikan Sistem Refrigerasi.

\section{DAFTAR PUSTAKA}

Adri, M. (2007). Pemanfaatan Internet Sebagai Sumber Pembelajaran. [Online]. Tersedia: http://directory.umm.ac.id/tik/Pemanfaatan_Internet_sebagai_ Sumber_Pembelajaran.pdf [3 Juli 2013].

Edy, I.C. (2010). Studi Pemanfaatan Web Site E-Learning dan Pengaruhnya terhadap Motivasi, Kinerja dan Hasil Belajar pada Guru dan Siswa SMK di Provinsi Jawa Tengah. [Online]. Tersedia: http://e-journal.stie-aub.ac.id/index.php/probank/ article/download/2/28 [3 Juli 2013].

Furqan. (2012). Pengertian Media Pembelajaran dan Ciri-ciri Media Pendidikan. [Online]. Tersedia: http://furqanwera.blogspot.com/2012/12/pengertian-media-pembelajarandan-ciri.html [30 Juli 2013].

Oetomo, B.S.D. et al. (2007). Pengantar Teknologi Informasi Internet: Konsep dan Aplikasi. Yogyakarta: CV. Andi Offset.

Purwanto. (2011). Evaluasi Hasil Belajar cet. ke-3. Yogyakarta: Pustaka Pelajar.

Rusman. et al. (2012). Pembelajaran Berbasis Teknologi Informasi dan Komunikasi cet. ke-2. Jakarta: PT. Rajagrafindo Persada.

Sahid. (2010). Pengembangan Media Pembelajaran Berbasis ICT. [Online]. Tersedia:http://staff.uny.ac.id/sites/default/files/131930136/Pengembangan Media Pembelajaran Berbasis ICT.pdf [26 April 2013].

Warsita, B. (2008). Teknologi Pembelajaran: Landasan dan Aplikasinya. Jakarta: Rineka Cipta. 